\title{
Effects of Heating and Storage on the Antifungal Activity of Camel Urine
}

\author{
Ahlam Al-Awadi and Awatif Al-Judaibi \\ Department of Biological Science, Microbiology Section, King Abdulaziz University, Jeddah, KSA, Saudi Arabia \\ *Corresponding author: Awatif Al-Judaibi, Department of Biological Science, Microbiology Section, King Abdulaziz University, Jeddah, KSA, Saudi Arabia, Tel: \\ 966505660345; E-mail: aamaljudaibi@kau.edu.sa
}

Rec date: Oct 09, 2014, Acc date: Nov 28, 2014, Pub date: Dec 21, 2014

Copyright: (C) 2014 Al-Awadi A, et al. This is an open-access article distributed under the terms of the Creative Commons Attribution License, which permits unrestricted use, distribution, and reproduction in any medium, provided the original author and source are credited.

\begin{abstract}
Camel urine, considered a 'miraculous' drug used in Prophetic Medicine, since the pre-Islamic era camel milk and urine were used as drinking medicine for different health problems. In addition, camel urine has proven to be effective as an antimicrobial agent, and may not have side effects for humans. Furthermore, camel urine may be resistant to factors such as high temperatures and an extensive waiting period in laboratory conditions, which can reduce the effectiveness of antibiotics. The aim of our study was to examine the effectiveness of camel urine as an antifungal agent following exposure to high temperatures and long time periods in laboratory conditions. After maintaining camel urine in natural laboratory conditions for 6 weeks at temperatures of up to $100^{\circ} \mathrm{C}$, we tested camel urine on the fungi Aspergillus niger and Fusarium oxysporum, and on the yeast Candida albicans. We then measured the dry weight of each microorganism, and determined their minimum inhibitory and fungicidal concentrations. Our results showed that after maintained for 6 weeks, camel urine did not lose its antifungal activity; dry weights following treatment were decreased $100 \%$ of the dry weight prior to treatment for Aspergillus niger and Candida albicans, and $53.33 \%$ for Fusarium oxysporum. Our study demonstrates that camel urine is a highly effective and resilient antifungal agent for treating human and plant fungal diseases.
\end{abstract}

Keywords: Camel urine; Antifungal; Candida albicans, Aspergillus niger, Fusarium oxysporum

\section{Introduction}

The camel is mentioned in the Holy Qur'an as a particularly important animal $^{1}$, and is referred to by other names such as al-ibil, alnagah, al-jamal, al-ishar and al-him [1]. Ccamel urine is considered a 'miraculous' drug used in Prophetic Medicine since the pre-Islamic era $^{2}$ [2], which has been used as traditional and folk medicine for women's hair; gums and teeth; skin injuries; snake bites; stomach pain; tumors; the common cold; diarrhea and nausea; diabetes; jaundice; scabies; and eye, skin, liver and nail infections [1-5]. Camel urine is also commonly used against cancer and respiratory tract infections in alternative medicine [6].

Camel urine has been proven to be effective as an antimicrobial agent, and may not have any side effects for humans [7]. Muhammad (1998) reported that patients who were given camel urine to treat digestion problems recovered after two months of treatment [8]. AlYousef et al. (2012) found that camel urine has no cytotoxic effect against mononuclear cells, and has strong immune activity by inducing IFN- $\gamma$ and inhibiting Th2 cytokines IL-4, IL-6 and IL-10. Kidney, liver and stomach tissues infected with Escherichia coli in mice recovered with no histopathological effects after treatment with camel urine of concentrations up to $100 \%$ [9-12]. Studies have tested the antimicrobial activity of camel urine against pathogenic microorganisms including the fungi Aspergillus niger, A. flavus, Fusarium oxysporum, Rhizoctonia solani, Aschocayta sp., Pythium aphanidermatum, Sclerotinia sclerotiorum, Candida albicans, and the bacteria Staphylococcus aureus, Streptococci, E. coli, Pseudomonas aeroginosa and Klebsiella pneomoniae. The results of these studies showed high antimicrobial activity against the tested microorganisms, even when accompanied by changes in anions and cations [4,13-18].

Antimicrobial activity of camel urine is due to factors such as high salt concentrations, alkalinity, natural bioactive compounds from the plants camels eat, resident bacteria, and excreted antimicrobial agents. Compared with other cattle, camel urine is alkaline due to high concentrations of potassium, magnesium and albuminous proteins, and low concentrations of uric acid, sodium and creatine [19-20]. The different composition of camel urine compared to other cattle and goats is due to the type of plants they consume and their feeding habits; camels prefer browse with high concentrations of minerals that decline more slowly when they dry instead of other types of forage such as grasses [21-23]. Further, camels eat a variety of types of vegetation including thorny bushes, halophytes, salty and sour plants, shrubs and aromatic species that are avoided by cattle and goat (e.g., Haloxylon aphyllum, H. persieum, Salsola gemmaseens, S. orientabs, Astragalus, Aristida karelinii and A.pinnate) [17,18,20,24].

The aim of our study was to investigate the resistance of camel urine to heating at high temperatures and storage for extensive waiting periods in laboratory conditions, which can reduce the effectiveness of antibiotics.

1 'Do they not look at the camel, how it was created?' (Surah Number 88: Al-Ghâshiyah).

2 Several Hadith in Sunnah talked about using camel urine and milk as medicine (the Saying of the prophet Muhammad, Volume 8, Book 82, Number 794: Narrated Anas): 'Some people from the tribe of 'Ukl came to the Prophet and embraced Islam. The climate of Medina did not suit them, so the Prophet ordered them to go to the (herd of milk) camels of charity, and to drink their milk and urine (as a medicine).' 


\section{Materials and Methods}

\section{Study materials}

The molds Aspergillus niger and Fusarum oxysporium were isolated and identified at the Cairo MIRCEN, Ain Shams University, Cairo, Egypt. Tested fungi were incubated at $28 \pm 2^{\circ} \mathrm{C}$. Candida albicans ATCC CA 10231 was incubated at $30 \pm 2^{\circ} \mathrm{C}$. Camel urine was collected from north Jeddah from live camel in the desert in sterilized dark bottles that were taken directly to the laboratory.

To investigate the effect of storage time and heating on camel urine antifungal activity, collected camel urine was divided into two major groups. The first group was further subdivided into three portions that were heated at 60,80 and $100^{\circ} \mathrm{C}$ for $60 \mathrm{~min}$. The second group was further subdivided into three portions that were stored for 3, 6 and 9 months before laboratory analyses. The positive control was fresh camel urine at $4^{\circ} \mathrm{C}$.

\section{Laboratory analyses}

The antimicrobial activity of camel urine was determined in vitro in response to $A$. niger, $F$. oxysporum and $C$. albicans. Activity levels were measured using disc diffusion and broth dilution, methods previously described by the Clinical and Laboratory Standards Institute (CLSI; formerly known as the National Committee for Clinical Laboratory Standards) [25,26]. For disc diffusion we used filter paper discs $(1 \mathrm{~mm}$ diameter impregnated with $100 \mu \mathrm{L})$, which were placed on the pre-inoculated agar surface. Negative controls were prepared with sterilized discs. Plates were then incubated at $28^{\circ} \mathrm{C}$ for $A$. niger and F. oxysporum for 7 days, and at $30^{\circ} \mathrm{C}$ for $C$. albicans for $48 \mathrm{~h}$. The inhibitory zones of each disc were measured. All tests were performed in triplicate.

The Minimum Inhibitory Concentration (MIC) and Minimum Fungicidal Concentration (MFC) of camel urine that inhibited the growth of fungi were investigated using a broth-microdilution method. C. albicans, $A$. niger and $F$. oxysporum were cultured and resuspended in $1 \mathrm{~mL}$ mueller-hinton broth (OXOID) to obtain a final concentration of $100 \mathrm{cfu} \mathrm{mL}-1$. Camel urine was serially diluted with Mueller-Hinton broth using methods approved by the National Committee for Clinical Laboratory Standards (M27- A) [27]. After incubation, the MIC was determined as the lowest concentration of extract for which there was no visible growth compared with the control $[28,29]$. The MFC was determined by inoculating $0.1 \mathrm{~mL}$ of negative growth at the MIC onto sterile Sabouraud Dextrose Agar SDA for $C$. albicans and Potato Dextrose Agar PDA for A. niger and $F$. oxysporum (OXOID) plates(Table 1). The plates were incubated at $30^{\circ} \mathrm{C}$ for $48 \mathrm{~h}$ for $C$. albicans, and at $28^{\circ} \mathrm{C}$ for 7 days for $A$. niger and $F$. oxysporum.

The lowest concentration of camel urine that did not demonstrate growth of the tested fungi was considered the MFC; the negative control was a plate grown with media only $[30,31]$.

The dry weight of the tested fungi was measured to determine the effects of recommended doses in Arab folk-medicine. $1 \mathrm{~mL}$ samples of $A$. niger and $F$. oxysporum spores, and $C$. albicans suspension (108 cfu $\mathrm{mL}-1)$ were inoculated into 5,10 and $15 \mathrm{~mL}$ samples of treated camel urine with SDB/PDB in $250 \mathrm{~mL}$ Erlenmeyer flasks. Flasks were incubated with shaking $(180 \mathrm{rpm})$ at $30^{\circ} \mathrm{C}$ for 7 days for $A$. niger and F. oxysporum, and for 48 hours for $C$. albicans. Afterwards, samples were collected and centrifuged at $10,000 \mathrm{rpm}$ for $10 \mathrm{~min}$. Fungal mycelia and yeast cells were collected. Growth was estimated as dry weight by washing with triple-distilled water and drying at $80^{\circ} \mathrm{C}$ on Whatman no. 1 filter paper until constant weight [32].

The lowest MICs of $1 \mu \mathrm{L} \mathrm{mL}-1$ were obtained with untreated camel urine; with urine treated at $60^{\circ} \mathrm{C}$ and $80^{\circ} \mathrm{C}$, and stored for 2 months for C. albicans, and with all treatments except for urine stored for 6 months for $A$. niger (Table 2). The most resistant fungus was $F$. oxysporum with MIC values ranging from 2 to $8 \mu \mathrm{L} \mathrm{mL}-1$. MFC values ranged from 4 to $32 \mu \mathrm{L} \mathrm{mL}-1$, and were lowest for $A$. niger and greatest for $F$. oxysporum (Table 3 ).

\section{Statistical Analysis}

The results were analyzed by paired-samples t-test using the IBM SPSS 20 statistical software to compare the mean values of each treatment. The results are expressed as means \pm SE. Probability levels of less than 0.01 were considered highly significant.

\section{Results}

We observed high inhibitory growth of $C$. albicans, $A$. niger and $F$. oxysporum after treatment with fresh camel urine, which provided evidence for camel urine as an active antifungal agent (Table 1). The most sensitive tested fungi were $C$. albicans and $A$. niger, while the inhibition of $F$. oxysporum only decreased by $22 \%$ when camel urine was stored for 6 months.

\begin{tabular}{|l|l|l|l|l|l|l|l|}
\hline & \multicolumn{3}{|l|}{ Incubation temperature } & \multicolumn{3}{l|}{ Storage time (months) } \\
\hline & Fresh & $\mathbf{6 0} 0^{\circ} \mathbf{C}$ & $\mathbf{8 0}{ }^{\circ} \mathbf{C}$ & $100^{\circ} \mathbf{C}$ & 2 & 4 & $\mathbf{2}$ \\
\hline C. albicans & $45 \pm 0.891^{* *}$ & $42 \pm 0.895^{* *}$ & $39 \pm 0.891^{* *}$ & $36 \pm 0.895^{* *}$ & $44 \pm 0.589^{* *}$ & $40 \pm 0.895^{* *}$ & $37 \pm 0.566^{* *}$ \\
\hline A. niger & $43 \pm 1.166^{* *}$ & $38 \pm 0.895^{* *}$ & $35 \pm 1.166^{* *}$ & $30 \pm 0.566^{* *}$ & $41 \pm 0.589^{* *}$ & $37 \pm 0.873^{* *}$ & $35 \pm 0.589^{* *}$ \\
\hline F. oxysporum & $39 \pm 0.895^{* *}$ & $36 \pm 0.895^{* *}$ & $34 \pm 0.589^{* *}$ & $29 \pm 0.589^{* *}$ & $37 \pm 0.891^{* *}$ & $35 \pm 0.566^{* *}$ & $32 \pm 0.566^{* *}$ \\
\hline
\end{tabular}

Table 1: Inhibition of $C$. albicans, A. niger and F. oxysporium growth after incubation with $100 \mu \mathrm{L}$ of camel urine.

\begin{tabular}{|l|l|l|l|l|l|l|l|}
\hline & \multicolumn{3}{|l|}{ Incubation temperature } & \multicolumn{3}{|l|}{ Storage time (months) } \\
\hline & Fresh & $60^{\circ} \mathrm{C}$ & $80^{\circ} \mathrm{C}$ & $100^{\circ} \mathrm{C}$ & 2 & 4 & 6 \\
\hline
\end{tabular}




\begin{tabular}{|l|l|l|l|l|l|l|l|}
\hline C. albicans & 1 & 1 & 1 & 2 & 1 & 2 & 2 \\
\hline A. niger & 1 & 1 & 1 & 1 & 1 & 1 & 2 \\
\hline F. oxysporum & 2 & 2 & 4 & 4 & 2 & 4 & 8 \\
\hline
\end{tabular}

Table 2: MIC ( $\mu \mathrm{L} / \mathrm{ml})$ of $C$. albicans, A. niger and F. oxysporium growth after treatment with serial concentrations of camel urine.

\begin{tabular}{|l|l|l|l|l|l|l|l|}
\hline & \multicolumn{4}{|l|}{ Incubation temperature } & & \multicolumn{2}{l|}{ Storage time (months) } \\
\hline & Fresh & $\mathbf{6 0} \mathbf{0}^{\circ} \mathbf{C}$ & $\mathbf{8 0 ^ { \circ } \mathbf { C }}$ & $\mathbf{1 0 0} \mathbf{C}$ & $\mathbf{2}$ & $\mathbf{4}$ & $\mathbf{6}$ \\
\hline C. albicans & 8 & 8 & 16 & 16 & 8 & 8 & 16 \\
\hline A. niger & 4 & 4 & 8 & 8 & 4 & 4 & 4 \\
\hline F. oxysporum & 8 & 16 & 16 & 32 & 16 & 32 & 32 \\
\hline
\end{tabular}

Table 3: MFC ( $\mu \mathrm{L} / \mathrm{ml})$ of $C$. albicans, A. niger and F. oxysporium growth after treatment with serial concentrations of camel urine.

Heating camel urine at different temperatures did not affect fungal dry weight (Table 4). Fungal growth was completely inhibited by $15 \%$ concentration of camel urine for all treatments and all tested fungi, and by 5 and $10 \%$ concentrations for most treatments. The activity of camel urine after heating at different temperatures increased compared with untreated camel urine; there was still $100 \%$ growth inhibition after treatment at $100^{\circ} \mathrm{C}$ for all tested fungi and all concentrations of camel urine. However, storage time increased the effect of inhibition for $C$. albicans and $F$. oxysporum at camel urine concentration of 5 and $10 \%$ (Table 5).

\begin{tabular}{|c|c|c|c|c|c|}
\hline \multirow[b]{2}{*}{ Temperature } & & \multicolumn{3}{|c|}{ Urine concentration (\%) } & \multirow[b]{2}{*}{15} \\
\hline & & 0 & 5 & 10 & \\
\hline \multirow[t]{3}{*}{ Untreated } & C. albicans & 20 & $5 \pm 2.207^{\star \star}$ & 0 & 0 \\
\hline & A. niger & 230 & $130 \pm 0.333^{* *}$ & 0 & 0 \\
\hline & F. oxysporum & 300 & $180 \pm 2.848^{* *}$ & $93 \pm 2.309^{* *}$ & 0 \\
\hline \multirow[t]{3}{*}{$60^{\circ} \mathrm{C}$} & C. albicans & 20 & $10 \pm 1.528^{*}$ & $10 \pm 1.528^{* *}$ & 0 \\
\hline & A. niger & 230 & 0 & 0 & 0 \\
\hline & F. oxysporum & 300 & 0 & 0 & 0 \\
\hline \multirow[t]{3}{*}{$80^{\circ} \mathrm{C}$} & C. albicans & 20 & $10 \pm 1.000^{* *}$ & $10 \pm 1.732^{*}$ & 0 \\
\hline & A. niger & 230 & 0 & 0 & 0 \\
\hline & F. oxysporum & 300 & 0 & 0 & 0 \\
\hline \multirow[t]{3}{*}{$100^{\circ} \mathrm{C}$} & C. albicans & 20 & 0 & 0 & 0 \\
\hline & A. niger & 230 & 0 & 0 & 0 \\
\hline & F. oxysporum & 300 & 0 & 0 & 0 \\
\hline
\end{tabular}

Table 4: Dry weight (mg) of $C$. albicans, $A$. niger and F. oxysporium after incubation with different concentrations of camel urine at different temperatures.

\begin{tabular}{|l|l|l|l|l|l|}
\hline Storage time & & \multicolumn{4}{|l|}{ Urine concentration (\%) } \\
\hline & & $\mathbf{0}$ & $\mathbf{5}$ & $\mathbf{1 0}$ & $\mathbf{1 5}$ \\
\hline Fresh & C. albicans & 20 & $5 \pm 2.207^{* *}$ & 0 & 0 \\
\hline & A. niger & 230 & $130 \pm 0.333^{* *}$ & 0 & 0 \\
\hline
\end{tabular}




\begin{tabular}{|c|c|c|c|c|c|}
\hline & F. oxysporum & 300 & $180 \pm 2.848^{\text {** }}$ & $93 \pm 2.309^{* *}$ & 0 \\
\hline \multirow[t]{3}{*}{2 months } & C. albicans & 20 & $10 \pm 0.333^{* *}$ & $10 \pm 2.028^{*}$ & $10 \pm 0.333^{* *}$ \\
\hline & A. niger & 230 & $110 \pm 0.667^{* *}$ & 0 & 0 \\
\hline & F. oxysporum & 300 & $290 \pm 2.028^{* *}$ & $210 \pm 0.333^{* *}$ & 0 \\
\hline \multirow[t]{3}{*}{4 months } & C. albicans & 20 & $10 \pm 0.333^{* *}$ & $10 \pm 0.333^{* *}$ & 0 \\
\hline & A. niger & 230 & 0 & 0 & 0 \\
\hline & F. oxysporum & 300 & $240 \pm 0.333^{* *}$ & $140 \pm 2.309^{* *}$ & 0 \\
\hline \multirow[t]{3}{*}{6 months } & C. albicans & 20 & $10 \pm 2.646^{*}$ & 0 & 0 \\
\hline & A. niger & 230 & 0 & 0 & 0 \\
\hline & F. oxysporum & 300 & $200 \pm 0.333^{* *}$ & $100 \pm 0.333^{* *}$ & 0 \\
\hline
\end{tabular}

Table 5: Dry weight (mg) of C. albicans, A. niger and F. oxysporium after incubation with different concentrations of camel urine for different periods of time.

\section{Discussion}

Camel urine is an efficient antimicrobial compound, particularly against Aspergillus sp., as demonstrated by our study and others [13,15-17]. Our results on the effects of heating and storage time on the antimicrobial activity of camel urine were consistent with the results of several other studies [33,34]. High inhibitory growth of the tested fungi, which were grown in an acidic environment, was due to the high alkalinity of camel urine as a result of high concentrations of $\mathrm{K}, \mathrm{Mg}, \mathrm{Ca}$ and proteins, and low concentrations of carbohydrate and cellulose [13,19-21].

Active compounds from plants that camels eat are excreted into the urine and increase its antimicrobial activity; these desert plants include Haloxylon aphyllum, H. persieum, Salsola gemmaseens, S. orientabs, Astragalus, Aristida karelinii, A. pennate, Citrullus colocynlhis schrad, Acacia eherenbergiana hayne, Dipterygium glaucum, Convolvulus hystrix vahl, Rhyzya stricta, Decne and Anabasis setifera Mog $[5,21,35]$. Camels spend more than $80 \%$ of their total feeding time on dicotyledons [21,36], which have more extracellular compounds compared to plants eaten by cattle, goat and sheep. Camels also graze on a variety of plants including thorny shrubs, halophytes and aromatic species that are avoided by cattle, goat and sheep [24], which ensures that active compounds such as flavonoids, alkaloids, terpenes, volatile and essential oils, anthraquinones, and phenolics are excreted in the urine [37-41].

Inhibited growth of $C$. albicans, $A$. niger and $F$. oxysporum reveals that the antimicrobial activity of camel urine was not affected by heating or storage time, perhaps because it was a high dose $100 \mu \mathrm{l}$; these results are reflected in the MIC and MFC. There was more of an effect of heating and storage time on the recommended dose of camel urine in Arab folk-medicine, which may be due to changes in the camel urine structure and composition as a result of treatment. AlAwade and Al-Judaibi (1999) explain that camel urine is very effective against microorganisms because of several components including bacteria that can survive under extreme conditions. These bacteria have special characteristics that enable them to live in conditions with high osmotic concentrations and alkalinity, and without nutrition. Further, these bacteria stay highly motile even after incubation at low temperatures. Our results show that the antimicrobial activity of camel urine increases after storage and heating up to $100^{\circ} \mathrm{C}$, which completely inhibited the growth of $C$. albicans, $A$. niger and $F$. oxysporum. Heating may increase the concentration of active compounds in urine by lysis of the bacterial cells, which in turn secrete enzymes and antibiotics. Storage time had no effect on the $15 \%$ concentration of camel urine. At high concentrations, more antibiotics are secreted by the bacteria, alkaline concentrations are higher and there are more active compounds from the plants.

The increased inhibitory effects on $C$. albicans and $F$. oxysporum at concentrations of 5 and $10 \%$ may be due to low concentrations of active compounds in the urine, which may allow the fungal cells to become more permeable to antibiotics and active compounds $[14,42,43]$.

The high antifungal activity of camel's urine reflected on the inhibition of the tested fungi and the results agreed with Al-Judaibi's results of camel's urine on A. niger and C.albicans compared with the antifungal agents Mycostatin, Pevaryl and Nizoral [44]. Several studies determined the effect of camel's urine on the cells and the results showed the efficient as repaired to the damaged cells, including the tumor cells and can be used as anticancer and antiplatelet activity against ADP-induced agent [8-11,45-47].

\section{Conclusion}

In conclusion, camel urine is a highly effective and resilient antifungal agent for treating human and plant fungal diseases. Our results confirm the traditional uses of camel urine as an antimicrobial agent, and may not have side effects for humans. In addition, heating and storage of camel urine did not alter the main fungicidal effects.

\section{References}

1. Bakhsh AA, WM EL-Deeb, A Al-Judaibi (2012) Camel Urine and Milk in the Arab Heritage (Folk Medicine): A Review. Camels in Asia and North Africa; Interdisciplinary perspectives on their significance in past and present. The Austrian Academy of Sciences for publication: 187- 192.

2. Baesmel S (2004) The milk and urine of the camel between the heritage and science. Journal of science and technology 18: 17-23. 
3. Mehari Y, Mekuriaw Z, Gebru G (2007) Potentials of camel production in Babilie and Kebribeyah woredas of the Jijiga Zone, Somali Region, Ethiopia. Livestock Research for Rural Development 19.

4. Al-Awadi A (1998) Features of the scientific miracles of the camel urine activity against the pathogenic Candida albicans and treatment of the skin diseases. The 2 nd conference of woman and scientific research at South Egypt. Assiut University.

5. Al-Awadi A, Al-Judaibi A (1999) Effect of camel's urine inhibitory growth of some pathogenic fungi and yeast. J Union Arab Biol 8: 335-363.

6. El-Elyani RA (1999) Some directories on the scientific miracles in prophetic mesicine effect of Camels urine and milk on the histological structure of kidney mice. J biolo Arabs, Cairo University 18.

7. Al-Kabarity AM, Al-Mazroee S, Al-Gendi A (1988) Camel urine as a possible anticarcinogenic agent. Arab Gulf J Scient Res Agric Boil Sci., 6: 55-63.

8. Muhammad AM (1998) A study of the chemical composition and some medical uses of the urine of Arabian camels, Al-Jazeerah University, thesis.

9. Al-Yousef N, Gaafar A, Al-Otaibi B, Al-Jammaz I, Al-Hussein K, Aboussekhra A (2012) Camel urine components display anti-cancer properties in vitro. Journal of Ethnopharmacology 143: 819-825.

10. Khalifa SA (1999) Some directories on the scientific miracles in prophetic mesicine effect of Camels urine and milk on the histological structure of liver mice. J Biolo Arabs, Cairo University 18.

11. EL-Elyani RAA, Khalifa SAM (2006) Histological Studies on the Effect of Camel's Urine and Milk on Stomach of Albino Mice. Saudi J Biolo Sci 13: 2 .

12. Khalifa S, AL-Elyani R, AL- Alwani A (2005) Histological, Cytological and Histochemical Studies on the Effect of Camel's Urine on Liver of Rabbits Infected By Escherichia coli. Saudi J Biolo Sci 12: 66-80.

13. AL-awadi A, AL-Judaibi A (2000) Antimicrobial agents in Camel's Urine. (9B) Microbiol Viruses 8: 265-281.

14. Al-Judaibi A (2010) Effect of mixed camel's urine and milk on dry weight and some metabolic activities of tested fungi. Proc. of the 3rd Animal Wealth Research Conf. in the Middle East \& North Africa: $414-420$.

15. Al-Judaibi A (2010) Effect of chemically treated Camel's Urine on growth and glucose uptake of some pathogenic fungi. Saudi Journal of Biological science 17: 177-186.

16. Al-Abdalall AHA (2010) The inhibitory effect of camel's urine on mycotoxins and fungal growth. African Journal of Agricultural Research 5: 1331-1337.

17. Al-Zahrani S (2002) Study on the effect of female camel's urine (virgin and fertilized) on the Aspergillus niger fungus. Arab Gulf J Sci Res 20: 115-122.

18. Al-Bashan MM (2011) In vitro assessment of the antimicrobial activity and biochemical properties of camel's urine against some human pathogenic microbes. Middle-East journal of scientific research 7: 947-958.

19. Kamalu TN, Okpe GC, Williams A (2004) Mineral contents of Extracellular Fluids in Camel and Cattle in the North East Sahel Region of Nigeria. Nigerian Veterinary Journal 24: 13-20.

20. Amer HA, Al-Hendi AB (1996) Physical, biochemical and microscopically analysis of camel urine. J Camel Practice Res. 3: 17-21.

21. Rutagwenda T, Lechner-Doll M, Schwartz HJ, Schultka W, von Engelhardt W (1990) Dietary preference and degradability of forage on a semiarid thornbush savannah by indigenous ruminants, camels and donkeys. Animal Feed Science and Technology 31: 179-192.

22. Kapu MM (1976) Cobalt and Iron contents of nineteen range forage species at two different growth periods in Northern Nigeria. Nig J Anim Prod 1:92.

23. Kapu MM, Lawal L (1976) Natural forages of Northern Nigeria. 2. Mineral status of some grasses and browse species from the Northern Guinea Savanna during the raining season. Nig J Amin Prod 1: 93.
24. Iqbal A, Khan BB (2001) Feeding Behavior of Camel, Review. Pak J Agri Sei 38: 58-63.

25. Fothergill AW (2011) Antifungal Susceptibility Testing: Clinical Laboratory and Standards Institute (CLSI) Methods. In: Intraction of Yeast, Moulds and Antifungal Agents, Hall, G.S. (Edn), Humana Press, New York: 65-74.

26. NCCLS (2004) Reference method for antifungal disk diffusion susceptibility testing of yeasts; approved guideline. NCCLS document M44-A. National Committee for Clinical Laboratory Standards, Wayne.

27. NCCLS (1997) Reference method for broth dilution antifungal susceptibility testing of yeasts. Approved standard M27-A. National Committee for Clinical Laboratory Standards, Wayne, Pa.

28. CLSI (2007) Performance standards for antimicrobial susceptibility testing. Proceedings of the 17th Information Supplement. CLSI Document M100- S17 (M2-A7 and M7-A7) 27. Clinical and Laboratory Standards Institute, Wayne, Pa.

29. CLSI (2008) Reference Method for Broth Dilution Antifungal Susceptibility Testing of Yeasts. (3rd Edn), Clinical and Laboratory Standards Institute, Wayne.

30. Ernst EJ, Roling EE, Petzold CR, Keele DJ, Klepser ME (2002) In vitro activity of micafungin (FK-463) against Candida spp.: Microdilution, timekill and postantifungal-effect studies. Antimicrobial Agents Chemotherapy 46: 3846-3853.

31. Wiegand I, Hilpert K, Hancock RE (2008) Agar and broth dilution methods to determine the minimal inhibitory concentration (MIC) of antimicrobial substances. Nat Protoc 3: 163-175.

32. Babu AG, Shim J, Bang KS, Shea PJ, Oh BT (2014) Trichoderma virens PDR-28: a heavy metal-tolerant and plant growth-promoting fungus for remediation and bioenergy crop production on mine tailing soil. J Environ Manage 132: 129-134.

33. Al-Awade AA, Heikal N (1997) Effect of camel's urine on growth and sporulation of Aspergillus niger. 1st Arab conference of applied chemistry, Cairo Egypt 1: 181-211.

34. Al-Awadi A, Al-Judaibi A (2001) Effect of antifungal camel's urine on the growth and some other metabolic activities of Aspergillus niger Gulf. J Sci 19: 44-51.

35. AL-Yahya MA, Hifnawy MS, Mossa J, AL-Meshal IA, Mekkawi A (1985) Aromatic plants of Saudi Arabia. Part 7: Essential oil of Plectranthus tenuiflorus Proc.8 sump. Saudi Biol Soc (AL-Hassa): 147-153.

36. Mukasa-Mugerwa E (1981) The Camel (Camelus dromedarius), a bibiographical review. The international Live Stock Center for Africa. ILCA Monograph. No 5 Addis Ababa.

37. Murthy GS, Bagyaraj DJ (1981) Flavonol and alkaloid content of pigeon pea cultivars resistance and susceptible to Fusarium udum. Indian phytopthol 33: 633-634.

38. O'Neil TM, Mansfield JW (1982) Antifungal activity of hydroxy flavons and other flavonoids. Trans Br Mycol Soc 79: 229- 237.

39. Sangwan RS, Agarwal K, Luthra R, Thakur RS, Neelam SS (1993) Biotransformation of arteannuic acid into arteannuin-B and artemisinin in Artemisia annua. Phyto Chemistry 34: 1301-1302.

40. Saxena VK, Shahai A, Samaiya G (1984) Studies on antimicrobial efficacy of essential oils of the leaves of Anaphalis contorta. Indian Perfumer 28: $177-178$.

41. Tsankova ET, Trendafilova AB, Kujumgiev AI, Galabov AS, Robeva PR (1994) Xanthanolides of Xanthium italicum Moretti and their biological activity. Z Naturforsch C 49: 154-155.

42. Brooks GF, Butel JS, Ornston LN (1995) Medical microbiology. AIANGE medical book Appleton and LANGE 20: 137.

43. Madigan MT, Martinko JM, Parkev J (1997) Brock Biology of microorganisms. Prentic Hall Inc 8: 421-422.

44. Al-Judaibi A (1999) Studies on the Antifungal Activity of Camel's Urine on Some Pathogenic Fungi Showing the Scientific Miracles in Sunnah. King Abdulaziz University, KSA, thesis.

45. Alhaidar A, Abdel Gader AM, Mousa SA (2011) The Journal of Alternative and Complementary Medicine 17: 803-808. 
Citation: Al-Awadi A and Al-Judaibi A (2014) Effects of Heating and Storage on the Antifungal Activity of Camel Urine. Clin Microbiol 3: 179. doi: 10.4172/2327-5073.1000179

Page 6 of 6

46. Alghamdi Z, Khorshid F (2012) Cytotoxicity of the Urine of Differen Camel Breeds on the Proliferation of Lung Cancer Cells, A549. Journal of Natural Sciences Research 2: 9-16.
47. Alhaider A, Sarwati S, Korashy H (2014) Camel milk and urine inhibits inflammatory angiogenesis in mice via downregulation of proangiogenic and proinflammatory cytokines (LB499), the FASEB journal, 28. 